\title{
Evolving Economic Policies and Disinvolving States: Notes in an African Context
}

\section{Jean-Marc Fontaine}

In this article I wish to do two things: first, to ask how much 'disinvolvement' of the state is justified on economic grounds in the case of Africa (points 1 to 3; the relevant document to which my argument will refer is the World Bank's latest Report on Development), and second, to sketch out a hypothesis concerning the link between disinvolvement and recent economic evolution (points 4 to 5 ).

1. The first point I would like to make concerns the meaning of terms such as 'disinvolvement' of the state or 'retreat'. I am not quite sure I clearly understand this concept. If one can guess what it meant in the 19th century European context, its relevance to present day Africa is a lot more problematic.

For instance, when Colonel Thomas Sankara took over in Upper-Volta (now Burkina Fasso) in 1983, he initiated a process which bore a lot of resemblance to policies advocated by the World Bank concerning size and modes of intervention of the public sector. Drastic budget reductions, cuts in pay and number employed in public administration, a general reduction of deficits, an upward shift in agricultural producerprices, tight control upon parastatal operations - and the demand that they meet financial equilibrium and an appeal to private sector investors to engage in new productive investment are examples of such public policy reforms. Roughly speaking, something like three-quarters of the World Bank's recommendations were met by Sankara without any World Bank intervention.

If one had to measure the 'degree' of involvement of the state in the economy through indicators such as the public budget or deficit expressed as a percentage of GNP, the volume of subsidies to parastatals, or, in orthodox neoclassical fashion, the extent of pricedistortion from a 'rational' norm, one would conclude that Burkina witnessed a disinvolvement of the state - and should pass the test of 'economic liberalisation'. I suppose, however, that very few people would maintain this position, if only because of the development of 'Comités de Défense de la Révolution' throughout the country.

Another illuminating example concerns the Ivory Coast, where an official disinvolvement of the state from parastatals ended up in 'privatising' these enterprises to the same set of people closely connected to the Houphouet Boigny family group, and retaining the same, although now more informal, privileged access to public financing networks and so on. ${ }^{1}$

This provokes two comments. The first is that in analysing the so-called disinvolvement of the state from the economy, or civil society, one should probably think not so much in terms of a degree of involvement, as measured, say, by the above mentioned indicators, as in terms of a modification in the forms of this involvement.

The second is that a 'non-disinvolved state', such as Burkina's, can achieve some of the structural reforms advocated by the World Bank under the heading of 'privatisation' or 'liberalisation', while an officially 'disinvolved' state such as the Ivory Coast might, in reality, fail to do so except in a formal and illusory way, so that the evolution of economic indicators is bound to be misleading as far as political institutions are concerned.

2. The second point I would like to make concerns the economic arguments put forward to justify this disinvolvement of the state.

For convenience, these arguments can be loosely grouped under two headings: i) control of inflationary pressures, and ii) economic efficiency.

The argument relating inflation control to state disinvolvement centres on the question of deficits. State intervention is seen as inflationary, either through budget deficit financing, or through subsidy schemes which, although not directly related to public budget management, end up in a very similar result.

This argument should really be split in two. One question is that of state mismanagement, exemplified by failures to recover taxes, diversion and misappropriation of public funds or overemployment in the civil service, and quite another one is that of deliberately running specific sectors on a financial deficitary basis offset by subsidy schemes. Obviously, these two sources of deficit ought to be separated even if one is solely concerned with inflation analysis. The fact that this distinction is not made by the World Bank and that subsidy schemes are systematically condemned is in itself revealing.

\footnotetext{
This is brought out in the preliminary findings of the research programme initiated by the Centre d'Etudes Africaines of the University of Bordeaux under the direction of Y. Fauré. I am grateful to Bernard Contamin, one of the participants in this programme, for this information.
} 
Granted that deficits are inflationary, curbing inflation by curbing deficits is not the whole story, especially when subsidy schemes have an impact on the cost of living. And subsidies on food, transport, petroleum products, or on agricultural inputs, including credit, do have such an impact. What is overlooked by the argument which attributes inflation to deficit-initiated monetary expansion is that by disposing of subsidy schemes, one creates the preconditions for another form of inflation, viz. costpush inflation via wage increases. ${ }^{2}$ The economic sequence is well-known: an upward shift in the cost of living will increase the cost of reproduction of labour. Although this will not necessarily end up in inflation, as wages may not follow, pressure in favour of such a move will certainly accumulate.

However, the trigger mechanism, i.e. the mechanism through which this pressure will actually be translated into nominal wage increases, is a political one. It has to do with bargaining, confrontation and the building up of positions of power. In other words, these two inflationary mechanisms have quite a different status both theoretically (deficit-induced inflation appears as mechanistic and unavoidable, while cost-of-living pressure can be contained) and politically (controlling money-supply appears as a purely technical matter, while pushing real income downward is clearly a matter of bargaining and dispute). If one had to construct a formal argument, then one could say that if an agency, such as the Bank, is to articulate recommendations regarding inflation, it is perfectly justified in approaching it from an exclusively monetary point of view, since any other move, such as a recommendation regarding what kind of bargaining should go on and to what outcome, could be characterised as political interference.

Now, the problem is that, by making recommendations based solely upon a monetary theory of inflation, and by exerting power to have them implemented, such agencies actually do make such political interventions, albeit implicitly: curbing inflation by curbing deficits assumes that real incomes of some part of the population must fall, i.e. that the state must intervene to withstand pressures for the restoration of income. ${ }^{3}$ So that resorting to an exclusively monetary approach

\footnotetext{
I realise that this section relies on a rather heavy assumption, viz. that income is determined by wages which are in turn to be appreciated in relation to the cost of living. Given that a small proportion of sub-Saharan Africa's population is actually engaged in formal wage-earning activities, the argument might need a lot of reworking. One could think of rephrasing it on the basis of an alternative formalisation of the wage-to-cost-of-living link, such as that presented by Matthiez in his studies of popular movements during the French revolution, where wages and non-agricultural prices were considered as fixed by tradition, and the adaptative variable was not the level of wages, but that of food [see long-term evidence in Bois]. Hence a very different scheme of oppositions, where bakers and grocers, and not employers, were the target of mobs, and royal authority the guarantor of food prices. I do not deal with this here.
}

to inflation when analysing the extent and scope of public sector intervention amounts to some kind of division of labour between the state and the international agencies, the latter dealing with 'technical' matters, whereas the former must face the consequent oppositions, with whatever strength it has at its disposal - which exemplifies the fact that control over money is an integral part of political sovereignty, and not a technical matter.

Hence, state 'disinvolvement' appears now as a more complex matter. Clearly it amounts both to a shift in the domestic forms of public intervention, from purely economic intervention - in the sense of based upon the tenets of economic analysis - to political intervention - in the sense of playing upon internal struggle and opposition - and to a renegotiation of spheres of sovereignty, through a shift in the balance between considerations of an internal vs. international nature, the internal 'disinvolvement' being matched by an international 'overinvolvement' of the state.

Obviously, these two shifts are related, and bear some correspondence to each other, as the 'politicisation' of state intervention is a facet of the internationalisation of monetary control.

Now, if abolishing subsidies were both an efficient and inescapable way of blocking inflation, and if inflation were a major crippling feature of sub-Saharan African economies, one might argue that this renegotiation of spheres of sovereignty between state and international agencies is justified - the World Bank and the IMF being then seen as lending their authority to a state which lacks the necessary strength to engage in painful but life-saving reforms. But there is quite a lot to be said against that view.

First, if there has undoubtedly been an acceleration of inflation in sub-Saharan African countries from the early 1970s onward, inflation has not been such a crippling problem, and probably not one of the most alarming structural features as it has been, say, in Latin America. Apart from a few exceptions (Zaire, Uganda, and Ghana, where annual rates of inflation shot up into the 50-60 per cent range during the 197384 period), sub-Saharan African rates of inflation overwhelmingly remained in the 10 to 15 per cent bracket, which are comparable to European rates (rates for France, Sweden, Denmark and Finland are around 10 to 11 per cent, and around the $14-18$ percent mark for the UK, Ireland, Spain and Italy). So although curing inflation is one of the problems to be dealt with by sub-Saharan countries, it is probably not the major problem to be tackled at any cost.

Second, sources of inflation in sub-Saharan countries have not been identified clearly enough to lend

Not to mention the bargaining process which will go on inside the state apparatus, designed to compensate, or defeat, those who benefited from, say, control of deficitary parastatals, as has been the case in Congo. 
sufficient authority to the money-based demand-pull theory of inflation [Schydlovsky 1982; Singh 1986] for it to govern economic policies.

Third, at least as far as agriculture is concerned, there most probably are alternative ways of handling subsidies which would very much reduce their deficitcontent [Sidhu and Sidhu 1985; Fontaine 1987], or even, when associated with a transfer of resources based upon small price differentials imposed by the state, bring this deficit content close to nil while exerting powerful effects on both production and distribution. ${ }^{4}$

As far as inflation is concerned, then, one should remain extremely sceptical about how much 'disinvolvement' of the state it warrants.

3. The second economic argument for liberalisation has to do with economic efficiency.

It rests mainly on two points, viz. i) that state-operated agencies are inefficient: either because, not being subjected to market pressures, they build up into monopolies, with their usual well-known uneconomic features, (in particular, not being submitted to costreduction constraints, they evade rationalisation); or because they are operated on a political logic, which always proves anti-economic in the end - and ii) that state intervention will interfere with market-forces, mess up relative prices, hence causing them to send inconsistent signals about scarcity structure, operation opportunities and so forth.

In contrast, in a country where the state does not interfere with economics, a coherent set of indicators is assumed to appear in the form of prices - or metaprices as they are sometimes called - so as to include, say, rates of interest or foreign exchange.

Now, although there certainly is some (probably large) scope for public rationalisation, one should also realise that the price-distortion argument can only be convincing in so far as the economy is strongly reactive to price changes. And this, in the case of sub-Saharan Africa - and quite probably in a number of other LDCs, including Latin-American countries - is probably not the case, either for behavioural reasons (if economic agents are more sensitive to other considerations than just price-based calculations, in which they perhaps simply don't engage ${ }^{5}$ - or for what we could loosely call structural reasons (if social

\footnotetext{
4 I am referring here to research work currently under way within the ROSA group in IEDES, Paris-1. the first results of which we hope to publish by December 1987.

A distinction. which I do not make in this article, is in order here, between price relationships which operate as a constraint - for instance, revenue from an activity should ensure a minimum economic viability in terms of reproduction of outlays, which might not always be the case in sub-Saharan African agriculture today and price relationships operating as an incentive, i.e. inducing an efficient allocation of resources, and pattern of production, through price changes. If these two cases can be shown to be identical undor restrictive theoretical assumptions, they certainly yield very different results in an economic policy context.
}

or physical relations are such that the operation of price mechanisms is hampered by discontinuities, bottlenecks, non-price constraints and so forth).

It should be noted, for instance, that agricultural sensitivity to prices - as measured by price elasticities - is low in Africa [Askari and Cummings 1977; Scandizzo and Bruce 1980; Bond 1983J, and is in the 0.1-0.4 range which means that to increase food production by 10 per cent - which is about the magnitude of an average country food-shortage - an increase of between something like 25 and 100 per cent in producer-prices is required, which might not be politically feasible, as Zambia, among others, experienced lately. This low response lends a lot of support to the so-called 'structuralist' approach to agriculture [Delgado and Mellor 1984; Rao 1986] which entails active state participation.

Another reason why economic decisions might not follow price indications is that, in countries which depend heavily upon imports for productive activities, and are endowed with a loose and ill-connected industrial network, major shifts in price structures, at least when induced by changes in the foreign rate of exchange, will not result in adaptative reactions unless they are accompanied by specific subsidy schemes designed either to reinforce or offset side-effects of reor de-valuations [Schydlowsky 1982]. To put it loosely, these economies appear more 'subsidy elastic' than 'exchange-rate elastic'.

From there on, one can wonder whether this argument should not be extended to the workings of the whole price mechanism. If one follows Schydlowsky's argument, this will certainly be true each time the rate of exchange is changed. Hence the question: what becomes, after devaluation, of the subsidy implemented to make devaluation effective? Will it be translated into a new price structure? And if so, who establishes these new prices, if not the state?

In other words, we are quite probably facing a paradox: effective operation of market mechanisms will require detailed intervention of the state, if only under the form of subsidy schemes. This simply means that a 'spontaneous' price mechanism either will not work as an effective decision-making procedure, or will send signals which, given both the behavioural pattern of producers and structural shortcomings of the countries, will provide misleading information. To sum up, to implement the 'liberal' economic regulation mechanism, i.e. a 'deregulated' market, and to make it work, require a 'non-liberal' politicaleconomic solution, namely, detailed state intervention.

4. Now, one could argue that all this is true, but concerns the past. African economies admittedly do not work according to market regulations, but if made to do so, would adapt, and eventually end up with more efficient and flexible regulation mechanisms. So the question is: will the disinvolvement of the state 
create conditions for an effective market mechanism to work?

This is a very big question and it can be answered only on the basis of political, historical and sociological findings.

However, the first thing one would like to ask is whether such a social transformation is on the agenda of 'liberalising' agencies such as the World Bank or the IMF. And if so (but see conclusions below) how do they go about achieving it? What are the effects of such a 'retreat' on various groups? Or, to put it another way, do the IMF and World Bank Stabilisation Programmes reinforce likely 'proto-bourgeois' groups?

To put it substantively, this amounts to asking whether there has emerged a class-formation which can assert itself independently of the state or, rather, in the context of general and unspecific forms of state intervention. Or at least, whether there has emerged such a 'proto-group' which could build up its power, given the right conditions.

My guess is that such examples will be scarce. Even if one admits that the last 20 years have witnessed the development of capitalist relations of production in Africa [Sender and Smith 1986], one will still be in search of an agent coherent enough, both economically and politically, to develop on its own momentum within the framework of indirect intervention by the state.

Numerous examples seem to indicate the contrary. In the Ivory Coast and Kenya, for instance, two countries which have the reputation of having adopted a successful market-oriented form of development, the various social groups engaged in production and accumulation can do so only in so far as they are at least closely connected to the state or, more generally, directly participate in government or public administration [Fauré and Médard 1982; Campbell and Bernstein 1985; Swainson 1980].

It should also be noted that the kind of accumulation pattern which evolves spontaneously, without active state intervention, often favours social groups which are perceived as expatriates, even when they actually are citizens of the countries in question, such as the Asians in East Africa or the Syrio-Lebanese in West Africa, resulting in autonomous production and accumulation models which are not politically feasible. In so far as liberalisation could produce an economically viable model, the political tensions it unleashes might be such that the state would have to intervene, if only to secure, say, 'Kenyanisation' or 'Ivoirisation' of the economy.

5. If we now look at the way in which economic liberalising tendencies were brought about, it is quite clear that they were not initiated domestically but largely resulted from international modifications, the forms of adaptation to which were not chosen by the countries themselves: we are not witnessing a 'revolution from above' as might be the case in China, but what one might call a 'revolution from over-above'.

It is quite obvious that country-wide economic management procedures have undergone a major shift in sub-Saharan African countries over the last ten years. This shift can be characterised as a movement away from planning and towards short-term management, which is also a movement away from physical planning towards monetary and financial management.

This entails a shift in the hierarchy of constraints, from the 1960-1970s to the 1980s, with the previous pyramid of priorities today standing on its head: monetary and financial matters now rank first, while they used to be considered as an appendix to physical planning procedures [Jacquemot 1984]. Obviously, financial equilibria were always considered, but they were derived from development plans rather than constraining them from the outset.

Following the change of emphasis in economic policy, a shift in economic management instruments has to occur, financial aggregates controls requiring that the stress be put on monetary management. This new set of economic instruments in turn implies a redefinition of state intervention [Fontaine 1982]. Clearly, such wide guidance procedures require that physical controls and detailed interventions be done away with, as they would become redundant, and hence contradictory, to overall management procedures. In other words, shifting to monetary control implies that the state should abstain from day-to-day specific interferences.

What we have here is an application of the general theoretical principle that money control requires the state to assume a position of 'exteriority' toward the economy. This is a point forcefully demonstrated by de Brunhoff [1973, 1976] who develops an illuminating analysis of the tensions between the requirements of 'exteriority' and 'immanence' in the 'Controle Etatique de la Monnaie' and which will be clearly understood by noting that managing money is managing the General Equivalent which operates at the basis of the 'sanction process' of productive activities. One can then link the retreat of the state from the economy to the adoption of new economic policy models.

International factors behind this evolution are well documented. From 1965 to 1984 , the deficit of the commercial balance moved from 2 to 7 per cent of GDP debt service to export ratio moved, between 1970 and 1984, from 5 to 14 per cent for poorer countries, and up to 20 per cent for intermediate income countries, while borrowing conditions were substantially aggravated: the proportion of debt submitted to variable rates of interest moved from 0.3 
to above 5 per cent for poorer countries and from 2 to 40 per cent for intermediate ones, the 'gift-element' on loans fell, between 1970 and 1982, from 46 to 15 per cent on public debt and from 13 to minus 13 per cent on private debt, while rates of interest roughly doubled in the same period (from 3.6 to 8.6 per cent on public debt, from 6.7 to 12.7 per cent for private debt).

None of this was offset by inflows of aid since, for the whole of sub-Saharan Africa, these remained roughly constant in nominal terms during the 1979-1984 period, a trend equally noted for private investment from abroad during the same period, both implying a dramatic decrease in real terms. Consequently, public deficits as a percentage of GDP rose from 3.9 to 4.4 per cent for poorer countries, and more than doubled (from 2.5 up to 5.4) for intermediate income countries, while the proportion of domestic savings to GDP halved from 13 to 6 per cent for poorer countries, and from 20 to 10 per cent for intermediate countries (excluding oil-exporters) [World Bank 1984 , 1986].

If one was to single out one set of factors, diminished foreign-exchange earnings, domestic savings, inflows of aid, and heavier and costlier debts, would provide at least as good an explanation for the strain put upon deficit, monetary and financial control as internal mismanagement failures, let alone the emergence of new classes or groups needing their economic autonomy in relation to an impeding over-interfering state.

6. To conclude, I would like to characterise disinvolvement as a form of articulation between subSaharan African states and the world economy, and ask a few questions.

If we wish to look at internal redefinitions of state/economy borderlines within an international context, the first thing we will need is a general hypothesis about late world-wide transformations. Convincing work has been produced by Ominami [1986], upon which we will rely here.

Three major features stand out: i) the rather good growth performance of LDCs - including those of sub-Saharan Africa - as compared to industrialised countries in the 1970s [Cline 1981] which damped down the crisis in these countries through a redirection of world-trade, but also ii) induced changes in the world division of labour which generally proved unfavourable to accumulation, and especially industrial development, in sub-Saharan Africa and iii) what could be called a 'financiarisation' of capital investment, not only because of over-liquidity in the early 1970s, but also because 'le capital-argent de prèt réussit à se soustraire à la dévalorisation que subit le capital industriel dans la crise' [Ominami quoting Chesnais 1983:104].

In view of this broad characterisation, what rationale can we find for this drift towards privatisation?

One element is 'Reaganist contagion [Ominami] both for ideological reasons and as a result of the worldwide influence and effects of US economic policies and deficits. What seems to be at work is something like a 'self-expanding' model, whereby deficits and modes of control initiated in the dominant Western country create such a situation that all other countries have to resort to one broad set of economic policies.

Another factor has to do with guaranteeing debtrepayment, or at least some minimal standards of international solvency, a point which touches on today's Achilles heel. However, in the case of Africa, default is perhaps not such a hazard (except in the case of Nigeria) as risks are concentrated on a few LatinAmerican countries, and anyway, one is not sure how effective present policies are in this respect.

A good guess, to end, could be that international agencies do not know what to do and resort to what they see as 'commonsense', viz. standard, and abstract, economics. The major problem however is that the regulation model consistent with debtmanagement based economic policies is not consistent with present-day economic and social structures in Africa, which simply will not fit in.

The ultimate question we are then left with is: what prospects does the retreat of the state open up for firm and clear-cut social stratification in Africa? Can it reinforce new groups, in industry, in the informal sector', will it reaccentuate the weight of rural-based classes? Or will the dismantling of the public sector also dismantle the only potential instrument for accumulation?

These are not questions economists can answer. They can only be put - and they ought to be put - to other hopefully more subtle and perceptive social scientists.

\section{References}

Askari, H. and J. T. Cummings, 1977, 'Estimating the agricultural supply response with the Nerlove Model: A Survey', International Economic Review, vol 18 no 2, June

Bois, G., 1976, La Crise du Féodalisme, Presses de la Fondation Nationale de Sciences Politiques, Paris (reprinted 1981)

Bond, M. E., 1983, 'Agricultural Supply Responses to Prices in sub-Saharan Africa', IMF Staff Papers, 30-4, Dccember

de Brunhoff, S., 1973, La Politique Monétaire, un essai d'interprétation Marxiste, Presses Universitaires de France, Paris

-1976, Etat \& Capital, Maspero/Presses Universitaires de Grenoble, Paris

Campbell, Bonnie and Henry Bernstein, 1985, Contradictions of Accumulation in Africa, Sage, New York, London and Toronto 
Chesnais, F., 1983, 'Aux antipodes de l'Euthanasie du Rentier', Colloque: Vers quel Nouvel Ordre Mondial? Université Paris VIII (mimeo)

Delgado, C. L. and J. W. Mellor, 1984, 'A Structural View of Policy Issues in African Agriculture', American Journal of Agricultural Economics, vol 66 no 5, December

Fauré, Y. and J. F. Médard, 1982, Etat et Bourgeoisie en Côte d' Ivoire, Karthala, Paris

Fontaine, J. M., 1982, 'L'Etat-Moins: limites de l'Etat chez les Néo-libéraux et les Economistes de l'Offre', Critiques de I'Economie Politique, Nlle. Serie, No 21, December

- 1987, 'Les Projets de Libéralisation des Agricultures Africaines, Economie et Société - Cahiers de I'ISMEA, July

Harvey, C., 1977, Macroeconomics for Africa, Heineman, London

Jacquemot, P., 1984, 'Crise et Renouveau de la Planification du Développement', Tiers-Monde, vol 25 no 98, June

Killick, T. (ed.), 1982, Adjustment and Financing in the Developing World, ODI/IMF, Washington

Mathiez, A., 1927, La Vie Chère et le Mouvement Social sous la Terreur, Volume I, Payot, Paris (reprinted 1973)

Ominami, C., 1986, Le Tiers-Monde dans la Crise, La Découverte, Paris
Rao, J. M., 1986, 'Agriculture in Recent Development Theory', Journal of Development Economics vol 22 no 1

Scandizzo, P. L. and C. Bruce, 1980, 'Methodology for Measuring Agricultural Price Incentive effects', World Bank Staff Working Papers, No 394, June

Schydlovsky, D., 1982, 'Alternative Approaches to Short Term Economic Management in Developing Countries' in T. Killick (ed.)

Sender, J. and S. Smith, 1986, The Development of Capitalism in Africa, Methuen, London

Sidhu, J. S. and D. S. Sidhu, 1985, 'Price support vs. fertiliser subsidy: an evaluation', Economic \& Political Weekly, Bombay, XX - 3, March

Singh, A., 1986, 'Tanzania and the IMF: the analysis of alternative adjustment programmes', Development and Change vol 17 no 3 , July

Swainson, Nicola, 1980, The Development of Corporate Capitalism in Kenya 1910-1977. Heineman, London and Nairobi

World Bank/IBRD, 1984, Un programme d'action concertée pour le Développement stable de l'Africa au Sud du Sahara. Washington DC

-1986, Rapport sur le Développement dans le Monde, Washington DC

\section{Books Received}

J. B. Singh, Raymond Myles and Anil Dhwssa, Manual on Deenbandhu Biogas Plant, Tata McGraw-Hill, New Delhi, 1987

James K. Boyce, Agrarian Impasse in Bengal: Agricultural Growth in Bangladesh and West Bengal 1949-1980, Oxford University Press, 1987

D. H. Perry, Starvation: the role of the market system, Australian National University, Canberra, 1986

C. G. Trapnell and M. A. Brunt, Vegetation and Climate Maps of South-Western Kenya, Land Resources Development Centre, Overseas Development Administration, 1987
Thomas O'Toole, The Central African Republic: The Continent's Hidden Heart, Gower, Aldershot, 1987

Deborah Pellow and Naomi Chazan, Ghana: Coping with uncertainty, Gower, Aldershot, 1987

Ken Darrow and Mike Saxenian, Appropriate Technology Sourcebook: a guide to practical books for village and small community technology, Volunteers in Asia, Stanford (Cal), 1986

Douglas Daniels (ed.), Evaluation in National Agricultural Research: Proceedings of a Workshop held in Singapore, 7-9 July 1986, IDRC, Ottawa, 1987

H. A. Holley, Developing Country Debt: the role of the commercial banks, Chatham House Papers 35, RIIA/ Routlege and Kegan Paul, London, 1987

Pierre Frühling (ed.), Stiedish Development in Perspective: Policies, Problems and Results since 1952, Ministry for Foreign Affairs, Stockholm, 1987 